Sains Malaysiana 50(11)(2021): 3275-3284

http://doi.org/10.17576/jsm-2021-5011-11

\title{
Pengasingan dan Pengesanan Asid Deoksiribonukleik (DNA) Spesies Haiwan menggunakan Multipleks Tindak Balas Rantaian Polimerase (PCR) daripada Minyak Sapi \\ (Isolation and Identification of Deoxyribonucleic (DNA) of Animal Species by Multiplex Polymerase Chain Reaction (PCR) from Ghee)
}

\author{
Nurul Hanisah Noor Azli, Sahilah Abd MutaliB* Haslaniza Hashim, MaAruf Abd Ghani \& Mohd \\ IZHAR ARIFF MOHD. KASHIM
}

\begin{abstract}
ABSTRAK
Kajian ini dijalankan untuk mengesan asid deoksiribonukleik (DNA) spesies haiwan dalam campuran minyak sapi menggunakan teknik tindak balas rantaian polimerase (PCR) multipleks. Kebolehdapatan DNA daripada produk berminyak membolehkan analisis PCR dijalankan dan sekaligus boleh menentukan kehadiran spesies haiwan produk tersebut dengan menggunakan primer haiwan yang khusus-spesies. Gen sasaran adalah DNA mitokondria (mtDNA) Sitokrom oksidase II (COII) untuk menentukan lembu, manakala mtDNA tRNA-ATP8 dan DNA nuklear (nDNA) Elemen Nuklear Berselang pendek (SINE) untuk menentukan babi. Terdapat satu kawalan (S1) dan tiga sampel campuran minyak sapi dengan gelatin babi ditambah pada kepekatan berbeza iaitu 1\%, 3\% dan 5\% (w/v) (S2, S3 dan S4). Analisis PCR simpleks menggunakan primer spesies-spesifik yang disebutkan, berjaya mengamplifikasi DNA lembu dengan amplikon bersaiz 165 bp (COII) dan DNA babi dengan amplikon 212 bp (tRNA-ATP8) dan 161 bp (SINE). Manakala, teknik PCR multipleks yang telah dioptimumkan menggunakan primer mtDNA (tRNA-ATP8) dan nDNA (SINE) untuk menentukan kehadiran haiwan babi, juga menghasilkan amplikon bersaiz yang sama. Oleh itu, kajian menunjukkan bahawa kaedah PCR multipleks adalah kaedah yang mudah, ringkas dan pantas untuk menentukan kehadiran DNA babi di dalam sampel campuran produk minyak sapi selain daripada kaedah PCR simpleks.
\end{abstract}

Kata kunci: Minyak sapi; PCR multipleks; pengasingan; pengenalpastian DNA; primer khusus-spesies

\section{ABSTRACT}

This study was conducted to detect deoxyribonucleic acid (DNA) of animal species in ghee mixture using polymerase chain reaction (PCR) technique. The availability of DNA from oily products allows PCR analysis to be carried out and at the same time can determine the presence of animal species of the product using species-specific animal primers. The target genes are mitochondrial DNA (mtDNA) cytochrome oxidase II (COII) to determine bovine, while tRNA-ATP8 mtDNA and nuclear DNA (nDNA) Short Intermediate Nuclear Elements (SINE) to determine porcine. There was one control (S1) and three samples of ghee mixture with porcine gelatine added at different concentrations of 1\%, 3\%, and 5\% (w/v) (S2, S3, and S4). Simplex PCR analysis using the species-specific primers mentioned above, successfully implicated bovine DNA with 165 bp amplicons (COII) and porcine DNA with 212 bp (tRNA-ATP8) and 161 bp (SINE) amplicons. Whereas, the multiplex PCR technique that has been optimized using mtDNA (tRNA-ATP8) and nDNA (SINE) primers to determine the presence of porcine, also produced amplicons of the same size as above. Therefore, studies show that the multiplex PCR method is an easy, simple and fast method to determine the presence of porcine DNA in ghee products mixed sample other than simplex PCR method.

Keywords: DNA identification; ghee; multiplex PCR; separation; species-specific primer

\section{PENGenALAN}

Lemak dan minyak ialah nutrien penting untuk tubuh manusia dan ia digunakan dalam penyediaan makanan bagi meningkat dan menghasilkan struktur, kestabilan, rasa, kualiti penyimpanan, ciri makan dan penampilan makanan serta nilai pemakanan kepada tahap yang dikehendaki oleh manusia (O’Brien 2000). Dalam industri makanan, lemak dan minyak adalah bahan berfungsi utama untuk pelbagai 
produk makanan. Mereka mempunyai sifat fizikal yang sangat penting dalam pemprosesan makanan semula jadi dan produk formulasi. Sebilangan besar makanan kegemaran dunia tidak dapat disediakan tanpa lemak dan minyak. Ini termasuk makanan bergoreng, pelbagai sos dan sos salad, produk bukan tenusu, toping, pastri, produk sapuan roti, susu formula bayi, snek, roti dan produk bakeri. Penggunaan lemak dan minyak, semakin meluas bukan sahaja dalam industri makanan dan minuman, tetapi juga dalam bidang farmaseutikal, kosmetik dan tekstil (Marikkar et al. 2005).

Ghee atau minyak sapi juga dikenali sebagai ghrit, ghritam, havi rognezard samn, samna dan maslea ialah produk susu lemak yang berasal dari India. Minyak sapi dikenali sebagai mentega jernih atau lemak susu kontang yang disediakan dengan memanaskan mentega atau krim kepada suhu melebihi $100{ }^{\circ} \mathrm{C}$ untuk mengeluarkan kandungan air dengan cara merebus dan penyejatan, kemudian menapis pepejal susu yang terhasil (Sharma et al. 2010). Minyak sapi merupakan lipid kompleks gliserida yang mengandungi asid lemak bebas, fosfolipid, sterol, ester sterol, vitamin larut lemak, kabornil, hidrokarbon dan karotenoid. Minyak sapi juga mengandungi zat besi dan kalsium serta kelembapan (Jariwala 2014). Kandungan utama minyak sapi adalah gliserida iaitu 98\% dan selebihnya 2\% adalah kolesterol. Profil asid lemak dalam minyak sapi adalah kompleks dan mempunyai kandungan lemak tepu dan kolesterol yang tinggi (Joshi 2014).

Pada masa kini, pengadukan bahan dalam produk makanan dengan lemak dan minyak mungkin berlaku sama ada dalam keadaan sengaja atau disebabkan pencemaran silang. Pengadukan adalah istilah undangundang untuk produk makanan yang tidak memenuhi piawaian tertentu dan ditakrifkan sebagai membuat makanan atau minuman yang kurang tulen dengan menambah bahan lain kepadanya dan akan menurunkan kualiti makanan atau minuman (Oxford Advanced Learner's Dictionary 2001). Lemak dan minyak adalah nutrien penting bagi manusia dan pengadukan antara lemak babi yang telah diubah suai dengan minyak sayuran untuk menghasilkan lelemak, marjerin dan minyak makanan lain mungkin boleh berlaku (Marikkar et al. 2005). Kajian tentang pemakanan menunjukkan lemak tepu yang biasanya didapati adalah minyak yang berasal daripada haiwan (Nurrulhidayah et al. 2012). Sehubungan dengan itu, kaedah pengesahan halal yang mudah dan murah amat diperlukan untuk melindungi pengguna Islam daripada penipuan yang melarang penggunaan produk babi (Nurrulhidayah et al. 2012). Kajian terdahulu banyak menjelaskan pengesanan kandungan babi dalam makanan dan produk farmaseutikal boleh dilakukan dengan tindak balas berantai polimerase (PCR) dengan mensasarkan gen DNA mitokondria (mtDNA)(Lahiff et al. 2001; Laila Liyana et al. 2018; Safiyyah et al. 2021, 2020) dan gen DNA nuklear (nDNA) (Calvo et al. 2001). Primer berasaskan mtDNA selalunya digunakan untuk mengenal pasti spesies DNA haiwan dalam analisis makanan kerana bilangan genomnya yang banyak di dalam sel ( 1 sel $=10^{4}$ salinan genom mtDNA), bersaiz lebih kecil dan lebih stabil haba berbanding dengan DNA nuklear (Sahilah et al. 2018, 2011). Walau bagaimanapun, nDNA juga dilaporkan boleh mengesan kehadiran DNA dalam produk makanan (Safiyyah et al. 2020). Ia digunakan dalam kajian ini, untuk membandingkan keupayaannya mengesan DNA babi berbanding dengan mtDNA.

Teknik PCR merupakan teknik yang sensitif, masa pemprosesannya cepat dan kosnya yang rendah. Walau bagaimanapun, terdapat perencat dalam sampel makanan. Justeru, kit pengekstrakan DNA komersial yang digunakan secara meluas dalam proses pengekstrakan DNA boleh membantu menghapuskan kehadiran perencat tersebut. Kit pengekstrakan DNA mengandungi proses menyahgaram untuk membuang makromolekul yang mencemarkan dan mengelakkan pelarut toksik organik (Shimizu \& Burns 1995). Kajian berkaitan pengesanan DNA babi dalam produk makanan amat penting di Malaysia bagi memastikan Malaysia kekal sebagai perintis produk makanan halal pada peringkat global. Dalam kajian ini, teknik PCR simpleks dan multipleks dijalankan untuk mengesan DNA spesies haiwan dalam ghee.

\section{BAHAN DAN KAEDAH}

\section{PERSAMPELAN}

Satu sampel produk lelemak iaitu minyak sapi jenama QBB Ghee dibeli daripada Pasaraya AEON, Taman Maluri, Cheras, Kuala Lumpur pada Februari 2015. Sampel gelatin babi turut digunakan dalam kajian ini bagi tujuan pencampuran dalam produk minyak (lembu dan babi). Sampel gelatin babi (G8150, Sigma USA) dicampurkan ke dalam minyak sapi pada kepekatan yang berbeza seperti yang dinyatakan dalam Jadual 1 . Gelatin babi dilarutkan dengan air terlebih dahulu dan dicampurkan ke dalam minyak sapi yang dicairkan di dalam relau pada suhu $120{ }^{\circ} \mathrm{C}$ dan kemudiannya dimasukkan ke dalam tiub emparan $50 \mathrm{~mL}$, supaya kepekatan akhir sampel mengandungi kepekatan 1\%, 3\% dan 5\% gelatin babi. Manakala, S1 adalah sampel tanpa gelatin babi $(0 \%)$ atau sampel kawalan. 
PENGASINGAN ASID DEOKSIRIBONUKLEIK (DNA)

Setiap sampel campuran $25 \mathrm{~mL}$ seperti yang dinyatakan sebelum ini ditambah dengan cecair penimbal fosfat $(\mathrm{pH}$ 7.0, $0.1 \mathrm{M}$ ) sebanyak $25 \mathrm{~mL}$. Kemudian, tiub divorteks dan diemparkan pada 13,000 rpm selama 20 minit. Terdapat tiga bahagian terbentuk. Bahagian tengah diambil, manakala bahagian atas dan bawah dibuang. Bahagian tengah diemparkan semula pada kelajuan yang sama selama 20 minit sehingga pelet terkumpul. Pelet kemudiannya dimasukkan ke dalam tiub emparan mikro $2 \mathrm{~mL}$ dan dieram semalaman pada suhu $56{ }^{\circ} \mathrm{C}$ bersama $400 \mu \mathrm{L}$ cecair penimbal fosfat dan $20 \mu \mathrm{L}$ proteinase $\mathrm{K}$ untuk melarutkan sisa protein. Campuran disejukkan pada suhu bilik dan diempar pada 13,400 rpm selama 5 minit. Sejumlah $500 \mu \mathrm{L}$ klorofom ditambah ke dalam tiub emparan mikro $2 \mathrm{~mL}$ yang baru dan $700 \mu \mathrm{L}$ lapisan atas jernih dipindahkan kepada tiub tersebut dan ditambahkan $1 \mathrm{~mL}$ cecair penimbal fosfat dan divorteks. Tiub kemudiannya diemparkan pada kelajuan 12,400 rpm selama 15 minit. Kemudian, keseluruhan campuran dimasukkan secara berperingkat ke dalam spin column dan diempar selama 2 minit pada 13,400 rpm bagi proses penapisan. Pada peringkat ini, DNA diesktrak menggunakan kit pengekstrakan DNeasy ${ }^{\circledR}$ Mericon Food (Qiagen, DE). DNA diukur untuk melihat kepekatan dan ketulenan DNA menggunakan Spektrofotometer (MaestroNano, MY).

\section{PRIMER OLIGONUKLETIDA}

Kesemua primer berserta jujukannya dalam kajian ini dipaparkan dalam Jadual 2. Kesemua primer dihasilkan dan dibekalkan oleh First Base Laboratories (Selangor, MY).

\section{AMPLIFIKASI TINDAK BALAS RANTAIAN POLIMERASE} (PCR)

Amplifikasi PCR dijalankan menggunakan mesin PCR Thermal Cycler (Applied Biosystems ${ }^{\circledR}$ Veriti ${ }^{\circledR}$, USA). Amplifikasi PCR telah dijalankan dengan isi padu akhir sebanyak $25 \mu \mathrm{L}$ yang dicampur dalam tiub emparan $0.5 \mathrm{~mL}$. MasterMix yang digunakan untuk amplifikasi PCR ini adalah DreamTaq Green PCR Master Mix 2X (Thermo Fisher Scientific, MY). Setiap campuran tindak balas mengandungi $12.5 \mu \mathrm{L}$ campuran induk (terdiri daripada 2X penimbal DreamTaq Green, dNTP dan 4 $\mathrm{mM} \mathrm{MgCl}_{2}$ ), $0.5 \mu \mathrm{L}$ untuk setiap primer (hadapan dan berbalik), $5 \mu \mathrm{L}$ templat DNA dan $6.5 \mu \mathrm{L}$ dengan Air Bebas Nukleare (NFW). Kawalan negatif DNA dilakukan dengan menambahkan $11.5 \mu \mathrm{L}$ NFW bagi menggantikan templat DNA dan kawalan positif dilakukan dengan menambahkan $5 \mu \mathrm{L}$ templat DNA komersial bagi lembu dan babi (Novagen $\AA$, Germany). Program PCR bagi proses pengamplifikasian pengesanan DNA haiwan adalah berbeza mengikut jenis primer.

Program PCR bagi pengesanan DNA lembu (Corona et al. 2007) adalah penyahaslian awal pada suhu $95^{\circ} \mathrm{C}$ selama 2 min diikuti oleh penyahaslian pada suhu $94{ }^{\circ} \mathrm{C}$ selama $1 \mathrm{~min}$, penyepuhan pada suhu $58^{\circ} \mathrm{C}$ selama 1 min, pemanjangan pada suhu $72{ }^{\circ} \mathrm{C}$ selama $1.5 \mathrm{~min}$ (sebanyak sepuluh kitaran). Penyahaslian pada suhu 90 ${ }^{\circ} \mathrm{C}$ selama $1 \mathrm{~min}$, penyepuhan pada suhu $58^{\circ} \mathrm{C}$ selama 1 min. Pemanjangan pada suhu $72{ }^{\circ} \mathrm{C}$ selama $1.5 \mathrm{~min}$ dan pemanjangan akhir pada suhu $72{ }^{\circ} \mathrm{C}$ selama $10 \mathrm{~min}$ (20 kitaran). Manakala, untuk primer babi mitokondria tRNA-ATP8 (Lahiff et al. 2001), penyahaslian awal pada suhu $95{ }^{\circ} \mathrm{C}$ selama $2 \mathrm{~min}$. Penyahaslian pada suhu 94 ${ }^{\circ} \mathrm{C}$ selama $1 \mathrm{~min}$, penyepuhan pada suhu $55^{\circ} \mathrm{C}$ selama $1 \mathrm{~min}$, pemanjangan pada suhu $72{ }^{\circ} \mathrm{C}$ selama $2 \mathrm{~min}$ dan pemanjangan akhir pada suhu $72{ }^{\circ} \mathrm{C}$ selama $10 \mathrm{~min}(30$ kitaran). Primer SINE (Calvo et al. 2001), penyahaslian awal pada suhu $94{ }^{\circ} \mathrm{C}$ selama 4 min. Penyahaslian pada suhu $94{ }^{\circ} \mathrm{C}$ selama $30 \mathrm{~s}$, penyepuhan pada suhu $50{ }^{\circ} \mathrm{C}$ selama $30 \mathrm{~s}$. Pemanjangan pasa suhu $72{ }^{\circ} \mathrm{C}$ selama $30 \mathrm{~s}$ dan pemanjangan akhir $72{ }^{\circ} \mathrm{C}$ selama 5 min (30 kitaran).

\section{TEKNIK TINDAK BALAS BERANTAI POLIMERASE (PCR) MULTIPLEKS}

Bagi tindak balas rantaian polimerase (PCR) multipleks, dua primer spesies-spesifik babi digunakan serentak dan perincian primer oligonukleotida telah dinyatakan dalam Jadual 2. Amplifikasi menggunakan kedua-dua primer iaitu tRNA-ATP8 dan SINE dilakukan secara serentak dalam satu proses PCR.

Pengamplifikasian DNA telah dijalankan dengan isi padu akhir sebanyak $25 \mu \mathrm{L}$ yang dicampur dalam tiub emparan $0.5 \mathrm{~mL}$. MasterMix yang digunakan untuk amplifikasi PCR ini adalah DreamTaq Green PCR Master Mix 2X Thermo Fisher Scientific. Campuran tindak balas mengandungi $12.5 \mu \mathrm{L}$ campuran induk (terdiri daripada $2 \mathrm{X}$ penimbal DreamTaq Green, dNTP dan $4 \mathrm{mM} \mathrm{MgCl2}$ ), $0.25 \mu \mathrm{L}$ untuk setiap primer (hadapan dan berbalik), $5 \mu \mathrm{L}$ templat DNA dan $6.5 \mu \mathrm{L}$ dengan Air Bebas Nukleare (NFW). Kawalan negatif DNA dilakukan dengan menambahkan $11.5 \mu \mathrm{L}$ NFW bagi menggantikan templat DNA dan kawalan positif dilakukan dengan menambahkan $5 \mu \mathrm{L}$ templat DNA komersial babi (Novagen ${ }^{\circledR}$, Jerman).

Pengoptimuman program multipleks PCR menggunakan kaedah cuba-jaya dilakukan bagi mengkaji 
keadaan yang optimum bagi kedua-dua primer. Jadual 3 menunjukkan tiga program pengoptimuman yang telah digunakan untuk PCR multipleks.

\section{ELEKTROFORESIS GEL AGAROSA}

Elektroforesis gel agarosa telah dilakukan ke atas larutan hasil tindak balas PCR menggunakan gel agarosa $2.5 \%(\mathrm{w} / \mathrm{v})$ pada $100 \mathrm{~V}$ selama $45 \mathrm{~min}$ bagi amplikon PCR multipleks, sitokrom oksidase II (COII) dan tRNA-
ATP8. Manakala, gel agarosa 2.0\% (w/v) bagi amplikon menggunakan primer SINE. Larutan penimbal Tris asid asetik EDTA (TAE) 1\% (w/v) digunakan sebagai medium larian manakala GeneRulerTM 168 penanda DNA bersaiz 100 bp digunakan sebagai rujukan anggaran saiz amplikon. Gel agarosa yang telah diprawarnakan dengan Maestrosafe ${ }^{\mathrm{TM}}$ Pre-Stained Nucleic Acid Stains (V-BioScience, MY) diperhatikan dan direkodkan menggunakan pengimbas gel Syngene GBOX EF2 (Syngene, UK).

JADUAL 1. Campuran minyak sapi dan gelatin babi

\begin{tabular}{lll}
\hline Sampel & $\begin{array}{l}\text { Kandungan campuran } \\
(25 \mathrm{~mL})\end{array}$ & Peratusan gelatin babi yang ditambah (w/v) \\
\hline S1 & Minyak sapi & Tiada campuran gelatin babi \\
S2 & Minyak sapi & $1 \%$ \\
S3 & Minyak sapi & $3 \%$ \\
S4 & Minyak sapi & $5 \%$ \\
\hline
\end{tabular}

JADUAL 2. Jujukan dan gen sasaran primer spesies-spesifik lembu dan babi

\begin{tabular}{|c|c|c|c|c|}
\hline Primer & Jujukan (5'-3') & $\begin{array}{l}\text { Sasaran } \\
\text { gen }\end{array}$ & $\begin{array}{l}\text { Saiz amplikon } \\
\text { (bp) }\end{array}$ & Rujukan \\
\hline Bovine & $\begin{array}{l}\text { H-5'-CAT CAT AGC AAT TGC CAT AGT } \\
\text { CC-3' } \\
\text { B-5'-GTA CTA GTA GTA TTA GAG CTA } \\
\text { GAA TTA G-3' }\end{array}$ & $\begin{array}{l}\text { Sitokrom oksidase II } \\
\text { (COII) }\end{array}$ & 165 & Corona et al. (2007) \\
\hline Babi & $\begin{array}{l}\text { H-5'-GCC TAA ATC } \\
\text { CCT CAA TGG TA-3' } \\
\text { D-5'-ATG AAA GAG GCA AAT AGA TTT } \\
\text { TCG-3' }\end{array}$ & $\begin{array}{l}\text { DNA mitokondria } \\
\text { tRNA-ATP8 }\end{array}$ & 212 & Lahiff et al. (2001) \\
\hline Babi & $\begin{array}{l}\text { H-5'-GGA TCC GGC ATT GCC GTT AG-3' } \\
\text { B-5'-GTC TTT TTT TGC CAT TTC TTG } \\
\text { G-3' }\end{array}$ & $\begin{array}{l}\text { Elemen Nuklear } \\
\text { Berselang pendek } \\
\text { (SINE) }\end{array}$ & 161 & Calvo et al. (2001) \\
\hline
\end{tabular}

H-hadapan, B-berbalik 
JADUAL 3. Program PCR multipleks bagi pengesanan DNA babi

\begin{tabular}{|c|c|c|c|c|}
\hline & Primer & Kaedah & Suhu $\left({ }^{\circ} \mathrm{C}\right)$ & Masa (min) \\
\hline \multirow[t]{5}{*}{1} & tRNA-ATP8 SINE & 1. Penyahaslian awal & $95^{\circ} \mathrm{C}$ & 3 \\
\hline & & 2. Penyahaslian & $94^{\circ} \mathrm{C}$ & 1 \\
\hline & & 3. Penyepuhan & $52{ }^{\circ} \mathrm{C}$ & 1 \\
\hline & & 4. Pemanjangan & $72{ }^{\circ} \mathrm{C}$ & 1 \\
\hline & & 5. Pemanjangan akhir & $72{ }^{\circ} \mathrm{C}$ & 7 \\
\hline \multirow[t]{5}{*}{2} & tRNA-ATP8 SINE & 1. Penyahaslian awal & $95^{\circ} \mathrm{C}$ & 3 \\
\hline & & 2. Penyahaslian & $94{ }^{\circ} \mathrm{C}$ & 1 \\
\hline & & 3. Penyepuhan & $53{ }^{\circ} \mathrm{C}$ & 1 \\
\hline & & 4. Pemanjangan & $72{ }^{\circ} \mathrm{C}$ & 2 \\
\hline & & 5. Pemanjangan akhir & $72{ }^{\circ} \mathrm{C}$ & 8 \\
\hline \multirow[t]{5}{*}{3} & tRNA-ATP8 SINE & 1. Penyahaslian awal & $95^{\circ} \mathrm{C}$ & 2 \\
\hline & & 2. Penyahaslian & $94{ }^{\circ} \mathrm{C}$ & 1 \\
\hline & & 3. Penyepuhan & $54{ }^{\circ} \mathrm{C}$ & 1 \\
\hline & & 4. Pemanjangan & $72{ }^{\circ} \mathrm{C}$ & 2 \\
\hline & & 5. Pemanjangan akhir & $72{ }^{\circ} \mathrm{C}$ & 9 \\
\hline \multirow[t]{5}{*}{4} & tRNA-ATP8 SINE & 1. Penyahaslian awal & $95^{\circ} \mathrm{C}$ & 2 \\
\hline & & 2. Penyahaslian & $94{ }^{\circ} \mathrm{C}$ & 1 \\
\hline & & 3. Penyepuhan & $55^{\circ} \mathrm{C}$ & 1 \\
\hline & & 4. Pemanjangan & $72{ }^{\circ} \mathrm{C}$ & 2 \\
\hline & & 5. Pemanjangan akhir & $72{ }^{\circ} \mathrm{C}$ & 10 \\
\hline
\end{tabular}

JADUAL 4. Ringkasan keputusan program pengoptimuman tindak balas polimerase (PCR) multipleks

\begin{tabular}{ll}
\hline Program PCR multipleks & \multicolumn{1}{c}{ Keputusan } \\
\hline Tindak balas 1 & Tiada amplikon terhasil \\
Tindak balas 2 & Tiada amplikon terhasil \\
Tindak balas 3 & Tiada amplikon terhasil \\
Tindak balas 4 & Dua jalur DNA kelihatan iaitu fragmen 161 bp dan 212 bp \\
\hline
\end{tabular}




\section{HASIL DAN PERBINCANGAN}

Kehadiran perencat dalam sampel makanan semasa analisis PCR menjadi faktor analisis PCR mendapat keputusan negatif terutamanya terhadap produk berminyak seperti minyak sapi. Kajian ini adalah cubaan yang dilakukan untuk mengasingkan DNA babi yang terdapat dalam gelatin babi yang kemudiannya dicampurkan dengan minyak sapi. Untuk menjalankan analisis PCR, penyingkiran perencat makanan dan pengekstrakan DNA yang berkesan semasa penyediaan sampel adalah penting supaya tidak mengganggu analisis PCR dan sekaligus berjaya mensasarkan gen spesies haiwan yang diamplifikasikan.

Setelah sampel minyak sapi dicampurkan dengan gelatin babi pada kepekatan yang berbeza (1\%, 3\%, 5\% $(\mathrm{w} / \mathrm{v}))$, pengekstrakan DNA adalah menggunakan kit. Tiada bacaan bagi kepekatan dan ketulenan DNA pada spektrofotometer dan ini menunjukkan kepekatan DNA yang mungkin terdapat dalam ekstrak tersebut terlalu rendah. Selain daripada itu, molekul kromofor yang sedikit di dalam ekstrak DNA mungkin tidak memberikan kekuatan warna apabila sinaran serapan ultra violet dikenakan (Thermo Scientific 2015). Produk minyak sapi mempunyai kandungan asid lemak yang mengandungi makromolekul seperti lipid yang kurang mengandungi molekul kromofor. Selain itu, gelatin yang ditambah ke dalam sampel campuran merupakan produk terproses dengan DNA terdegradasi dan menjadi serpihan yang lebih pendek. Ini menyebabkan kesukaran untuk mengekstrak DNA dan menjalankan amplifikasi PCR seperti yang dilaporkan oleh penyelidik sebelum ini (Mafra et al. 2008). Walaupun spektrofotometer gagal mengesan bacaan DNA yang diekstrak, kajian ini diteruskan untuk analisis PCR bagi menentukan kehadiran gen sasaran haiwan lembu dan babi, pada kepekatan DNA yang rendah.

Analisis PCR dilakukan untuk mengamplifikasikan DNA yang telah diekstrak daripada sampel pada gen sasaran bagi pengesanan spesies lembu. Keputusan menunjukkan amplikon 165 bp kelihatan seperti yang ditunjukkan dalam Rajah 1. Kaedah pengekstrakan ini berjaya mendapatkan DNA lembu dalam minyak sapi. Berdasarkan pemerhatian ini, didapati sampel bagi Lajur S1 dan S2 menunjukkan keamatan jalur DNA yang agak terang berbanding sampel pada Lajur S3 dan S4 yang menunjukkan jalur DNA yang pudar. Keamatan jalur amplikon mungkin bergantung kepada kepekatan DNA yang diekstrak di dalam sampel yang dikaji. Bagi Lajur $\mathrm{NC}$, tiada sebarang jalur DNA kelihatan seperti yang telah dijangka. Lajur PC pula menunjukkan jalur DNA lembu kawalan berjaya diamplifikasi dan ia amat penting bagi menunjukkan sampel dalam Lajur S1, S2, S3 dan S4 menghasilkan fragmen yang betul dan menunjukkan saiz yang sama seperti jalur DNA kawalan lembu. Kajian ini selari dengan kajian oleh Corona et al. (2007) yang telah menggunakan primer DNA mitokondria (mtDNA) lembu yang mensasarkan gen sitokrom oksidase II (COII). Dalam kajian tersebut, teknik PCR spesies spesifik telah berjaya menghasilkan fragmen $165 \mathrm{bp}$ untuk DNA lembu, walaupun DNA tersebut mungkin telah banyak terdegradasi semasa pemprosesan haba dikenakan. Dalam kajian ini, walaupun minyak sapi telah dicairkan dengan suhu yang agak tinggi iaitu $120{ }^{\circ} \mathrm{C}$, namun gen sasaran COII masih boleh diamplifikasi dan menghasilkan amplikon bersaiz 165 bp. Gen sasaran COII telah digunakan dalam kebanyakan kajian dan dianggap sebagai rujukan pengesanan sasaran DNA mitokondria (mtDNA) bagi meningkatkan peluang untuk mendapat keputusan yang positif daripada sampel yang dikenakan suhu yang tinggi semasa pemprosesan (Pascoal et al. 2005; Prado et al. 2002).

Seterusnya, primer tRNA-ATP8 menghasilkan amplikon 212 bp bagi sampel yang mengandungi DNA babi seperti yang ditunjukkan dalam Rajah 2. Berdasarkan pemerhatian keputusan ini, didapati sampel bagi Lajur S2, S3 dan S4 menunjukkan jalur DNA yang pekat dan menunjukkan kehadiran DNA babi bersaiz 212 bp. Manakala bagi Lajur S1, tiada sebarang jalur DNA yang kelihatan kerana tiada DNA babi untuk diamplifikasi. Bagi Lajur NC, tiada sebarang jalur DNA kelihatan dan perkara ini telah dijangkakan. Lajur PC pula menunjukkan jalur DNA babi kawalan berjaya diamplifikasi dan menunjukkan sama aras dalam gel agarosa terhadap sampel dalam Lajur S2, S3 dan S4. Primer SINE yang mensasarkan gen nuklear, juga menunjukkan kesemua lajur S2, S3 dan S4 yang positif (Rajah 3) tetapi berbeza keamatan berbanding dengan primer mitokondria tRNA-ATP8 (Rajah 2). Perbezaan keamatan adalah disebabkan salinan DNA di dalam mitokondria DNA (mtDNA) adalah lebih banyak berbanding salinan DNA nuklear (Corona et al. 2007). Oleh itu, semakin banyak jumlah peratusan gelatin babi yang ditambah dalam campuran minyak sapi dan lelemak haiwan, semakin pekat jalur DNA babi yang dapat diamplifikasi. Selain daripada itu, Calvo et al. (2001) menjelaskan dalam kajian beliau bahawa DNA babi berjaya dikesan menggunakan kepekatan DNA babi yang rendah, serendah $0.1 \%$ dan $1 \%(\mathrm{w} / \mathrm{w})$ dengan menggunakan primer SINE. Kajian ini juga menunjukkan keputusan yang serupa tetapi tidak melakukan ujian DNA babi pada kepekatan 0.1\% (w/v) gelatin babi.

Dalam kajian ini, cubaan untuk mensasarkan gen berganda menggunakan kaedah multipleks telah 
dilakukan. Primer t-RNA-ATP8 dan SINE digunakan bagi mendapatkan keputusan yang positif. Terdapat 4 program analisis PCR dikenakan terhadap DNA yang diekstrak seperti program yang tersenarai dalam Jadual 3. Program ke-4 berjaya menghasilkan amplikon berganda seperti yang ditunjukkan dalam Rajah 4. Keamatan kepekatan 5\% (w/v) menunjukkan kepekatan yang lebih baik berbanding dengan keamatan pada Lajur S2 dan S3. Keamatan pada Lajur S3 menunjukkan jalur yang berbeza untuk t-RNA-ATP8 iaitu lebih terang berbanding SINE lebih pudar. Ini mungkin disebabkan DNA sasaran untuk primer SINE lebih sedikit berbanding dengan DNA sasaran
t-RNA-ATP8. Gen sasaran SINE berasal daripada nuklear manakala t-RNA-ATP8 berasal daripada mitokondria yang mempunyai salinan DNA yang lebih tinggi. Kajian ini konsisten dengan kajian oleh Cheng et al. (2012) yang juga menyatakan DNA mitokondria merupakan primer yang lebih berkesan digunakan berbanding DNA nuklear dalam pengesanan DNA babi. Teletchea et al. (2005) juga melaporkan, DNA yang telah mengalami degradasi dan terubah suai, masih boleh mengamplifikasikan gen sasaran selagi gen sasaran tidak musnah. Tiada jalur pada Lajur S1 kerana tiada gelatin babi diletakkan dalam sampel S1, oleh itu tiada DNA sasaran terdapat padanya.

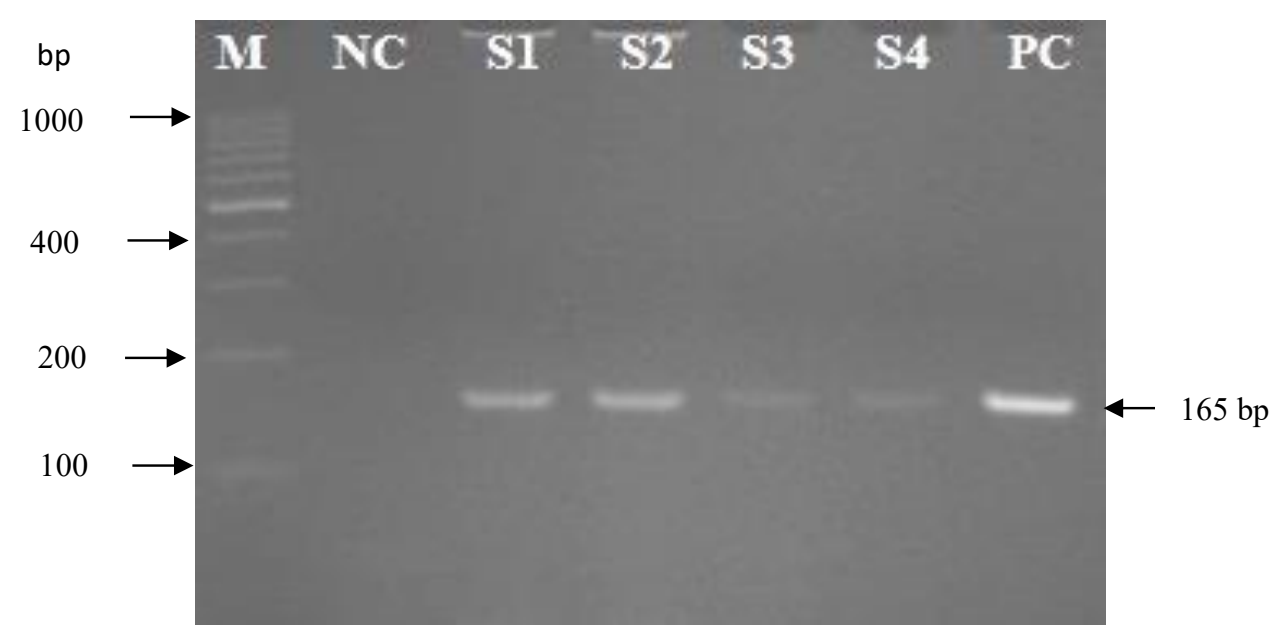

RAJAH 1. Hasil amplifikasi PCR spesies spesifik lembu menggunakan primer DNA mitokondria (mtDNA) sitokrom oksidase II (COII) untuk lembu. Lajur M: Tangga 100 bp; NC: Kawalan negatif; Lajur S1: Ekstrak DNA minyak safi tanpa gelatin; Lajur S2: Ekstrak DNA minyak safi dan $1 \%(\mathrm{w} / \mathrm{v})$ campuran gelatin; Lajur S3; Ekstrak DNA minyak safi dan $3 \%(\mathrm{w} / \mathrm{v})$ campuran gelatin; Lajur S4: Ekstrak DNA minyak safi dan 5\% (w/v) campuran gelatin; dan Lajur PC: Kawalan positif lembu amplikon bersaiz 165 bp

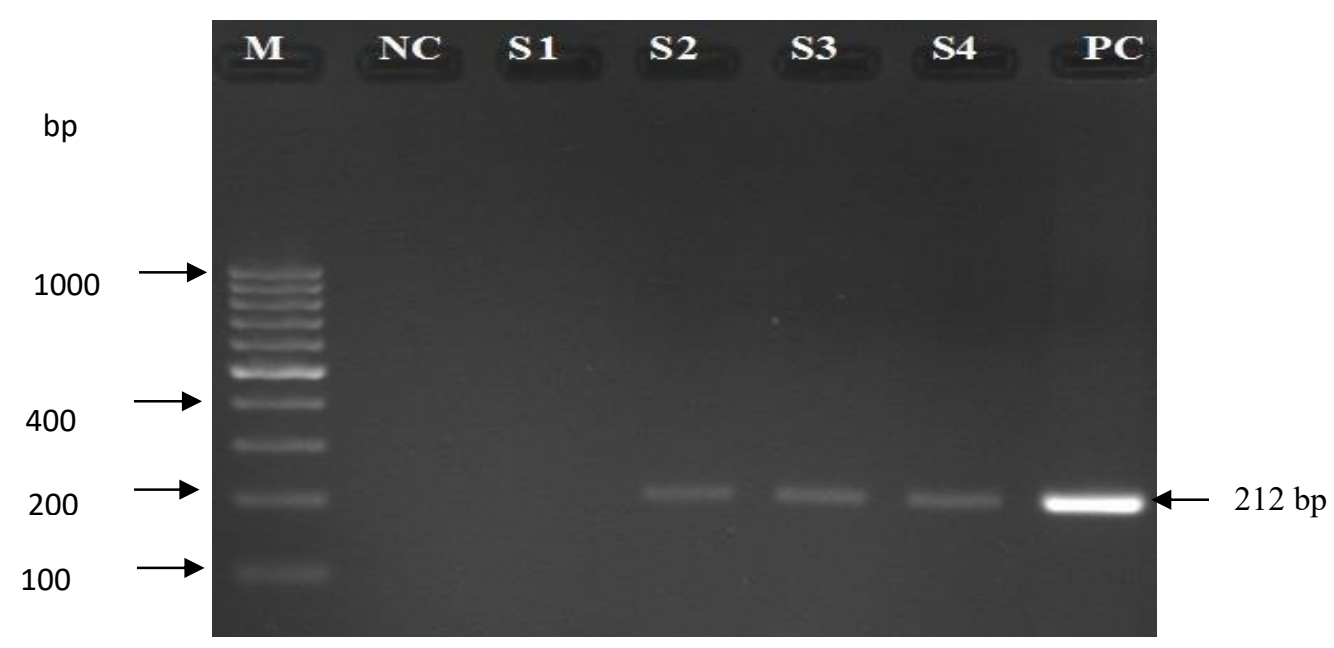

RAJAH 2. Hasil amplifikasi PCR spesies spesifik babi menggunakan primer DNA mitokondria (mtDNA) tRNA-ATP8. Lajur M: Tangga 100 bp; NC: Kawalan negatif; Lajur S1: Ekstrak DNA minyak safi tanpa gelatin; Lajur S2: Ekstrak DNA minyak safi dan 1\%

(w/v) campuran gelatin; Lajur S3; Ekstrak DNA minyak safi dan 3\% (w/v) campuran gelatin; Lajur S4: Ekstrak DNA minyak safi dan 5\% (w/v) campuran gelatin; dan Lajur PC: Kawalan positif babi amplikon bersaiz 212 bp 


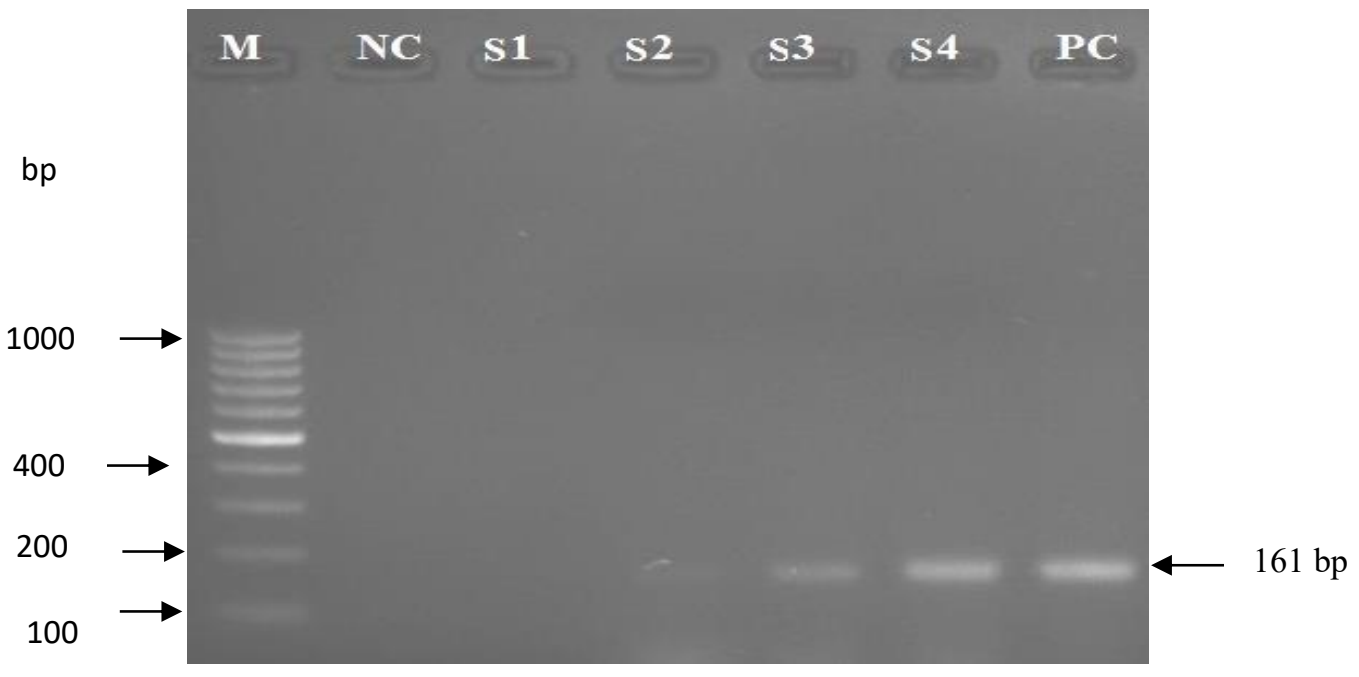

RAJAH 3. Hasil amplifikasi PCR spesies spesifik babi menggunakan primer DNA nuklear (nDNA) SINE. Lajur M: Tangga 100 bp; NC: Kawalan negatif; Lajur S1: Ekstrak DNA minyak safi tanpa gelatin; Lajur S2: Ekstrak DNA minyak safi dan 1\% (w/v) campuran gelatin; Lajur S3; Ekstrak DNA minyak safi dan 3\% (w/v) campuran gelatin; Lajur S4: Ekstrak DNA minyak safi dan 5\% (w/v) campuran gelatin; dan Lajur PC: Kawalan positif babi amplikon bersaiz $161 \mathrm{bp}$

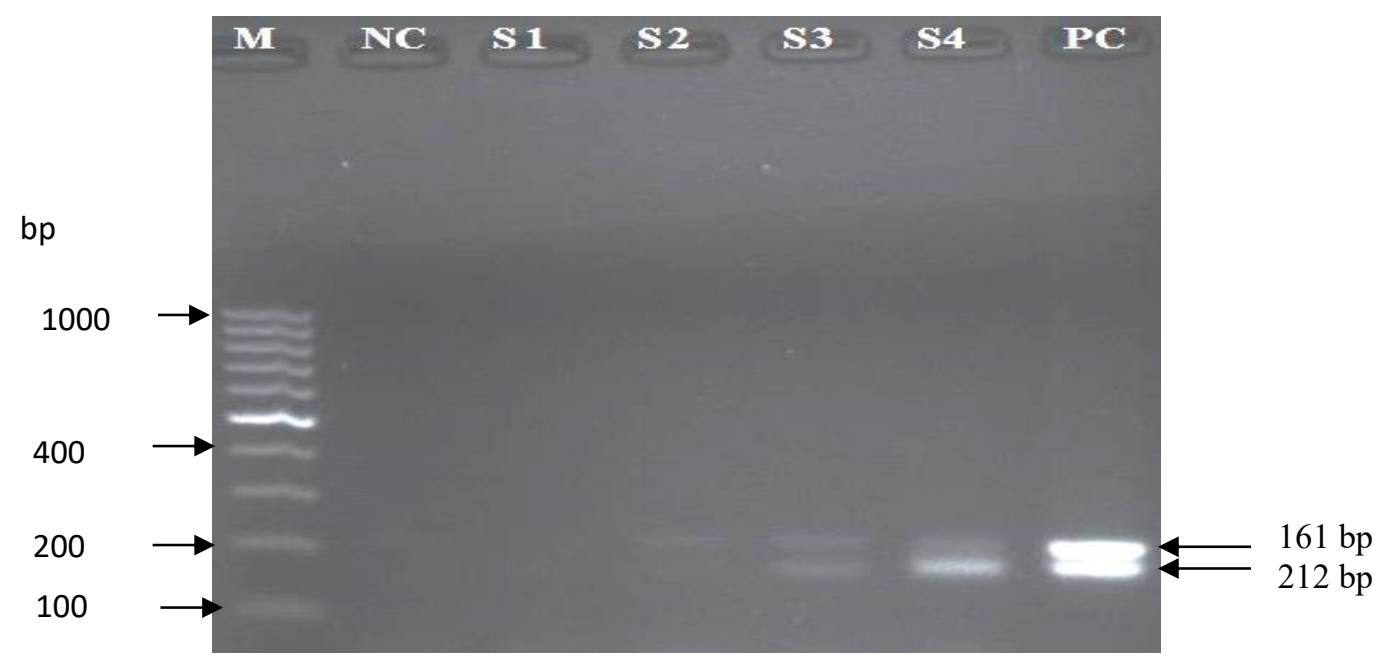

RAJAH 4. Hasil amplifikasi multipleks PCR babi menggunakan primer DNA mitokondria (mtDNA) tRNA-ATP8 dan DNA nuklear (nDNA) SINE. Lajur M: Tangga 100 bp; NC:

Kawalan negatif; Lajur S1: Ekstrak DNA minyak safi tanpa gelatin; Lajur S2: Ekstrak DNA minyak safi dan 1\% (w/v) campuran gelatin; Lajur S3; Ekstrak DNA minyak safi dan 3\% (w/v) campuran gelatin; Lajur S4: Ekstrak DNA minyak safi dan 5\% (w/v) campuran gelatin; dan Lajur PC: Kawalan positif babi amplikon bersaiz161 dan 212 bp

\section{KESIMPULAN}

Kesimpulannya, kajian ini menunjukkan bahawa DNA babi masih boleh diasingkan daripada media berlemak dan analisis PCR boleh dilakukan bagi mengesan DNA babi dengan menggunakan dua jenis primer yang berbeza. Sama ada primer yang mensasarkan gen berasal daripada 
mitokondria atau gen yang berasal daripada nuklear. Analisis pengesanan DNA babi ini amat berkesan, cepat dan mudah bagi membantu pengesanan DNA haiwan dalam produk makanan terproses.

\section{PENGHARGAAN}

Kami mengucapkan terima kasih kepada Universiti Kebangsaan Malaysia (UKM) atas sokongan peralatan dan bahan kimia yang digunakan. Kajian ini dijalankan dengan menggunakan dana GGP-2020-015 \& AP2017$002 / 1$.

\section{RUJUKAN}

Calvo, J.H., Zaragoza, P. \& Osta, R. 2001. Technical note: A quick and more sensitive method to identify pork in processed and unprocessed food by PCR amplification of a new specific DNA fragment. Journal of Animal Science 79: 2108-2112.

Cheng, X.L., Wei, F., Xiao, X.Y., Zhao, Y.Y., Shi, Y., Liu, W., Zhang, P., Ma, S.C., Tian, S.S. \& Lin, R.C. 2012. Identification of five gelatins by ultra performance liquid chromatography/ time-of-flight mass spectrometry (UPLC/Q-TOF-MS) using principal component analysis. Journal of Pharmaceutical and Biomedical Analysis 62: 191-195.

Corona, A., Lieonard, R., Carpio, Y., Uffo, O. \& Martinez, S. 2007. Short Communication. PCR detection of DNA of bovine, ovine-caprine and porcine origin in feed as part of a bovine spongiform encephalopathy control program. Spanish Journal of Agricultural Research 5: 312-317.

Jariwala, K.N. 2014. Analytical techniques for the assessment of physico-chemical properties of ghee. Indian Journal of Applied Research 4(6): 216-217.

Joshi, K.S. 2014. Docosahexaenoic acid content is significantly higher in ghrita prepared by traditional Ayurvedic method. Journal of Ayurveda \& Integrative Medicine 5(2): 85-88.

Lahiff, S., Glennon, M., Lyng, J., Smith, T., Maher, M. \& Shilton, N. 2001. Species- specific PCR for the identification of ovine, porcine and chicken species in meat and bone meal (MBM). Molecular and Cellular Probes 15: 27-35.

Laila Liyana, M.N., Sahilah, A.M., Nur Qistina, Z., Mohd Khan, A., Aminah, A. \& Abdul Salam, B. 2018. Detection of porcine DNA in cooked meatballs using polymerase chain reaction (PCR) assay. International Food Research Journal 25(5): 1953-1958.

Mafra, I., Ferreira, I.M.P.L.V.O. \& Oliveira, M.B.P.P. 2008. Food authentication by PCR-based methods. European Food Research and Technology 227: 649-665.

Marikkar, J.M.N., Ghazali, H.M., Che Man, Y.B., Peiris, T.S.G. \& Lai, O.M. 2005. Distinguishing lard from other animal fats in admixtures of some vegetable oils using liquid chromatographic data coupled with multivariate data analysis. Food Chemisty 91: 5-14.
Nurrulhidayah, A.F., Che Man, Y.B., Mohammad, A.J. \& Suhaimi, A.R. 2012. The contribution of science and technology in determining the permissibility (halalness) of food products. Revelation and Science 2(1): 1-8.

O'Brien, R.D. 2000. Utilization of fats and oils. In Introduction to Fats and Oils Technology. 2nd ed., edited by O'Brien, R.D., Farr, W.E. \& Wan, P.J. Illinois: AOCS Press.

Oxford Advanced Learner's Dictionary. 2001. 6th ed. Oxford: University Press.

Pascoal, A., Prado, M., Calo, P., Cepeda, A. \& Velasquez, J.B. 2005. Detection of bovine DNA in raw and heat-processed foodstuffs, commercial foods and specific risk materials by a novel specific polymerase chain reaction method. European Food Research and Technology 220(3-4): 444450.

Prado, M., Franco, C.M., Fente, C.A., Cepeda, A., Vázquez, B.I. \& Barros-Velázquez, J. 2002. Comparison of extraction methods for the recovery, amplification and species-specific analysis of DNA from bone and bone meals. Electrophoresis 23(7-8): 1005-1012.

Safiyyah, S., Sahilah, A.M., Wan Sakeenah, W.N., Aminah, A. \& Norrakiah, A.S. 2018. Comparison of DNA profiling between fishes and pork meat using polymerase chain reaction-restriction fragment lenght polymorphisms (PCR-RFLP) analysis. Sains Malaysiana 47(7): 15351540.

Safiyyah, S., Nur Syafiqa, A.G., Aishah, E., Nurul Aqilah, M.Z. \& Sahilah A.M. 2020. Analisis tindak balas berantai polimerase (PCR) simpleks dan multipleks ke atas produk surimi terawat terma bagi pengesanan DNA lembu dan babi. Sains Malaysiana 49(8): 1959-1967.

Safiyyah, S., Sahilah, A.M., Norfadzilah, I., Aishah, E., Haslaniza, H. \& Mohd Izhar Ariff Mohd Kashim. 2021. Species-specific identification of porcine blood plasma in heat-treated chicken meatballs. Saudi Journal of Biological Sciences 28(4): 2447-2452. https://doi.org/10.1016/j. sjbs.2021.01.043.

Sahilah, A.M., Norhayati, Y., Norrakiah, A.S., Aminah, A. \& Wan Aida, W.M. 2011. Halal authentication of raw meats using PCR amplification of mitchondrial DNA. International Food Research Journal 18(4): 1489-1491.

Sharma, H., Zhang, X. \& Dwivedi, C. 2010. The effect of ghee (clarified butter) on serum lipid levels and microsomal lipid peroxidation. An International Quarterly Journal of Research in Ayurveda 31(2): 134-140.

Shimizu, H. \& Burns, J.C. 1995. Isolation of DNA from paraffin-embedded tissue using the Master Tm Complete DNA and RNA purification kit. In PCR Strategies, edited by Innis, M.A., Gelfand, D.H. \& Sninski, J.J. London: Oxford University Press.

Teletchea, F., Maudet, C. \& Hanni, C. 2005. Food and forensic molecular identification: Update and challenges. Trends in Biotechnology 23: 359-366. 
Thermo Scientific. 2015. Chromatography or Foods and Beverages Fats and Oils Analysis Applications Notebook: Solvable Solutions for Hydrophobic Compounds. http:// www.thermoscientific.com/content/dam/tfs/ATG/CMD/ cmd- documents/sci-res/app/chrom/market/AI-71471Chromatography-Foods- Beverages-Fats-Oils-AI71471-EN. pdf. Diakses pada 2 Julai 2015.

Nurul Hanisah Noor Azli, Sahilah Abd Mutalib* Haslaniza Hashim \& Maaruf Abd Ghani

Department of Food Sciences

Faculty of Science and Technology

Universiti Kebangsaan Malaysia

43600 UKM Bangi, Selangor Darul Ehsan

Malaysia
Sahilah Abd Mutalib*

Innovation Centre for Confectionery Technology (MANIS)

Faculty of Science and Technology

Universiti Kebangsaan Malaysia

43600 UKM Bangi, Selangor Darul Ehsan

Malaysia

Mohd Izhar Ariff Mohd. Kashim

Centre of Shariah, Faculty of Islamic Studies

Universiti Kebangsaan Malaysia

43600 UKM Bangi, Selangor Darul Ehsan

Malaysia

*Pengarang untuk surat-menyurat; email: sahilah@ukm.edu.my

Diserahkan: 18 Oktober 2020

Diterima: 9 Mac 2021 